\title{
DO ESG METRICS REFLECT CRISIS RESILIENCE OF EQUITIES DURING THE COVID-19 PANDEMIC?'
}

Fanni Dudás - Helena Naffa ${ }^{2}$

\begin{abstract}
We examine the role of ESG metrics in explaining crisis resilience during the COVID-19 pandemic. ESG refers to Environmental, Social, and Governance aspects of companies, collectively known as ESG factors, and has gained popularity in investments. Our empirical tests cover a database of 971 company members of the MSCI World Index and examine the COVID Crisis period from February 2020 - May 2020. We performed linear regression and Owen-Shapley decomposition in our study, like the literature. Our results show that ESG is not an "equity vaccine" but is a statistically significant and economically important variable in explaining returns during the pandemic. Our findings highlight the increasing importance of sustainability aspects in finance and in investing.
\end{abstract}

JEL codes: Go1, Q56, G30

Keywords: ESG, crisis resilience, pandemic, linear regression, Owen-Shapley decomposition

\section{INTRODUCTION}

The global crisis induced by the COVID-19 pandemic caused a sharp and severe shock to global equity markets on 20 February 2020. That shock lasted for almost three months, but international equity indices soon recovered with the reassurances of central banks that provided liquidity to the markets. As the long-term impact of the pandemic is yet to unfold, this paper examines the effects of the

1 The present publication is the outcome of the project „From Talent to Young Researcher project aimed at activities supporting the research career model in higher education”, identifier EFOP3.6.3-VEKOP-16-2017-00007 co-supported by the European Union, Hungary, and the European Social Fund.

2 Fanni Dudás, PhD student, Corvinus University of Budapest. E-mail: fanni.dudas@uni-corvinus. hu.

Helena Naffa PhD, associate professor at Corvinus University of Budapest. E-mail: helena.naffa@ uni-corvinus.hu. 
crisis of COVID-19 from the perspective of ESG equity investments at macro and company level.

While in general, almost all asset classes and equity investments uniformly took a sudden hit (correlation tended to 1 ) as news of the global scale of the pandemic surfaced, the impact was more diverse, with some sectors emerging as beneficiaries of the crisis, while others remain challenged. According to Günther et al. (2020), firms, such as Lufthansa, Adidas, or US airlines, sought financial support from their governments to remain liquid. On the other hand, beneficiaries of the crisis include technology companies and healthcare sector players. Fears of the crisis spiralling towards an economic recession were dispelled by the swift and colossal liquidity central banks provided to the markets, supported by a lenien fiscal policy across the globe. Hence, we refer to the short period between 20 February 2020 - May 2020 as the "COVID Crisis" (CC). This paper focuses on the crisis resilience of companies during the $\mathrm{CC}$ with attention to the role of ESG metrics.

In this research, the sustainability of companies is measured by ESG metrics. Sustainable finance is one of the latest trends in finance literature today, lagging behind the other sciences in researching the problem of sustainability (NaffaFain, 2020; Tamásné Vöneki-Lamanda, 2020). In contrast, macroeconomists have previously addressed sustainability and climate risk (Naffa-Fain, 2020; Németh-Durkó, 2020). Several studies examine the relationship between environmental (E), social (S), and governance (G) factors (Primecz-Havran-Lakatos, 2019; Berlinger, Keresztúri-Tamásné Vőneki, 2019). Nowadays, sustainability considerations are taking centre stage, with asset owners becoming increasingly aware of ESG aspects. However, transition to a sustainable economy is not a clear and easy path for investors and companies. Long-term value creation contrasts with the traditional investment approach, which focuses on short-term profittaking and considers financial risk only. In contrast, long-term value creation integrates economic, social, and environmental values and addresses financial and sustainability risks (Schoenmaker and Schramade, 2019). In this paper, we identified sustainability aspects using the ESG indicators of companies. Environmental, Social, and Governance aspects are collectively known as ESG factors, which have recently gained significant importance in finance. According to MSCI ESG Research (MSCI, 2016), these are unique performance indicators that measure an investment's sustainability and societal impact. ESG factors and ratings apply both to companies and countries, similarly to credit ratings.

During the COVID pandemic, many suspected that a good ESG rating would provide a kind of protection for companies; in the media ESG was termed an "equity vaccine" against the CC. This theory based on corporate social responsibility activities helps build social capital and trust in corporations. The bond will motivate a company's stakeholders to remain loyal (Demers, 2021). Many studies support this theory, such as Albuquerque et al., 2020; Bouslah et al., 2018; Cornet et al., 2016; Ding et al., 2020; 2021. On the other hand, based on agency theory, researchers found the opposite: ESG does not provide downside risk protection (Lys et al., 2015).

This paper's research question uncovers how ESG aspects played a role in the resilience of firms during the first shock of the global pandemic from 1 February 2020 to 1 May 2020 and whether a relationship exists between the ESG performance of firms and their crisis resilience. First, we investigated the determinants of crisis resilience and examine whether including ESG indicators improve the model's explanatory power. Then we analysed the decomposition of the $\mathrm{R}$ square of each regression to determine the exact contributions of the explanatory variables to the R-Square of a linear regression (Israeli, 2007). We performed linear regression and Owen-Shapley decomposition in our study. Our results have shown that ESG is not an "equity vaccine" but it is a statistically significant and economically important variable in explaining returns during the pandemic.

The paper is structured as follows: we summarize the literature and introduce the investment market background. Next, we present the hypotheses, the user database and outline the applied methodology. We conclude with the results of our research and discussion.

\section{LITERATURE REVIEW}

Crisis resilience was addressed in the literature in the context of countries as well as companies. Papers (Oprea et al., 2020; Alessi et al., 2020) studied crisis resilience at regional or country level, but there is a lack of research to uncover crisis resilience at company level. ESG and the relationship between returns and stock value have long been a research topic in the literature (Demers et al., 2021; $\mathrm{Li}$ ang-Renneboog, 2020). The novelty of this paper lies in examining the ESG aspect of corporate-level crisis resilience and addressing the exact contributions of the explanatory variables, which have not been discussed in the literature thus far.

Sabatino (2016) identified seven characteristics that define corporate crisis resilience: “1) Product focalization; 2) geographic focalization; 3) quickness in the decision; 4) organizing structure based on the clan model; 5) strong national imprinting-business values; 6) "customer centricity"; 7) an efficient system of incentives for strategic aims".

Armeanu et al. (2017) examined the risk management aspects of crisis resilience. They believed that good corporate governance upholds effective risk management, allowing flexibility to respond to unpredicted threats and to benefit from 
opportunities. Therefore, risk management affords corporate resilience that gives rise to competitive advantage due to the capacity to circumvent, deter, defend, react, and adjust to any disturbance, besides recovering quickly. They examined listed companies of Romania and found that the gender of the CEO, the size of the Board, and the Audit Committee are in negative relationship in connection with business failure risk.

Castro and Zermeno (2020) studied the resilience factors such as attitudes adopted towards the crisis, the characteristics of the business and the entrepreneur, the relationships with institutions, human and social capital, and strategic management. They believe that these factors can be considered in training programmes for resilient entrepreneurs and by the different actors in the entrepreneurial ecosystem, including universities and public policymakers, who support them. Several researchers have also examined financial resilience in recent years.

Soroka et al. (2020) examined the QuiScore credit score to measure corporate and regional economic resilience. A single study examined the usefulness of the indicator, and the results showed that QuiScore is an effective indicator of the financial resilience of firms.

Markman and Venzin (2014) argue in their article that there are basically few good examples in the literature that would be robust measures of the economic resilience of firms. Their study developed a unique crisis resilience indicator that combines financial performance metrics with firm volatility data. Their results suggest that the resilience of these firms is driven by a combination of their resource capacity, market context, and industrial conditions. One of the objectives of our research is to examine the current situation and expand the literature on the economic resilience of companies.

Many academic studies focused on the role of ESG as a mitigator of downside risk during a crisis period. According to Godfrey et al. (2009), some types of CSR activities will be more likely to create goodwill and offer insurance-like protection against downside risk, especially during a crisis.

Some researchers have found evidence that higher investments in ESG may result in socially responsible firms becoming less vulnerable during a crisis. For example, Ding et al. (2020) evaluated the connection between corporate characteristics and stock price reactions to COVID-19 cases. They found that the pandemic-induced drop in stock prices was milder among firms with (a) stronger pre-2020 finances (more cash, less debt, and more significant profits), (b) less exposure to COVID-19 through global supply chains and customer locations, (c) more CSR activities, and (d) less inveterate executives. Furthermore, they found that the stock returns of firms controlled by families, large corporations, and governments performed better, while those owned by hedge funds and other asset management compa- nies performed worse. Stock markets assess low levels of managerial ownership positively, but high levels of managerial ownership negatively during a pandemic (Ding et al., 2021).

Many scholars have examined ESG investments and sustainability aspects during the coronavirus crisis. Broadstock et al. (2021) used empirical tools to examine the question whether the ESG performance of firms reduces financial risk during a crisis. As a result, portfolios with a high ESG score generally performed better than portfolios with a low ESG score.

Albuquerque et al. (2020) analysed how firms with better environmental and social (ES) ratings performed in the first quarter of 2020 compared to other firms during the coronavirus crisis. Their research found evidence that high ES-rated stocks yield significantly higher returns, lower volatility, and have higher trading volumes than other stocks. Companies with high ES ratings and increased advertising spending performed exceptionally well during the crisis. This article highlights the importance of EU policies in making companies more resilient during a crisis.

Günter et al. (2020) examined how financially sustainable firms performed during the coronavirus crisis. They used four indicators to measure financial sustainability and applied these measurements to investment portfolios of a broad sample of firms from 15 European countries of the MSCI Europe. Their research has found that financially sustainable firms outperformed both the overall market and firms of low financial sustainability from July 2019 to March 2020.

Bouslah et al. (2018) examined the impact of the Global Financial Crisis (GFC) on the relationship between a firm's risk and social performance using a database of non-financial US firms. They have found that social performance and risk are significantly different during a crisis and in the post-crisis period compared to the pre-crisis period. Social performance reduces volatility during a financial crisis.

The study of Cornett et al. (2017) focused on the relationship between banks' corporate social responsibility (CSR) and financial performance in the context of the Global Financial Crisis (GFC). Their results confirm banks generally appear to be rewarded for being socially responsible as financial performance is positively and significantly related to CSR scores.

On the other hand, studies support the theory that higher investments in ESG may result in socially responsible firms becoming more vulnerable during a crisis, based on the agency theory. It suggests that ESG investments are sometimes wasteful managerial self-serving expenditures funded from corporate coffers they could be destructive to shareholder valu. (Demers et al., 2021).

Lys et al. (2015) agree with this theory. They have found that corporate social responsibility expenditures are neither corporate charity nor do they improve fu- 
ture financial performance: ESG expenditures generate insufficient returns and reduce shareholder value.

\section{THEORETICAL FRAMEWORK}

In our study, we build on the economic resilience model of Martin (2012). He developed the idea of flexibility, examined its use in understanding how regional economies responded to significant recession shocks, and cited British regions as exploratory examples. Martin defined economic resilience as a shock-triggered process and distinguished four phases: resistance, recovery, reorientation, and diversion. Resistance refers to the first direct response to a recession and measures the intensity and extent of the decline. In comparison, it relates to the speed and volume of how an economy can recover from a downturn and return to its original growth path.

Given that our research is fundamentally short-term, we will examine the first components of the model. We enhance Martin's (2012) model to include sustainability aspects: ESG aspects as determinants. On this page, the present study model is structured as follows (Figure 1):

\section{Figure 1}

\section{Our model, based on Martin's (2012) resilience model}

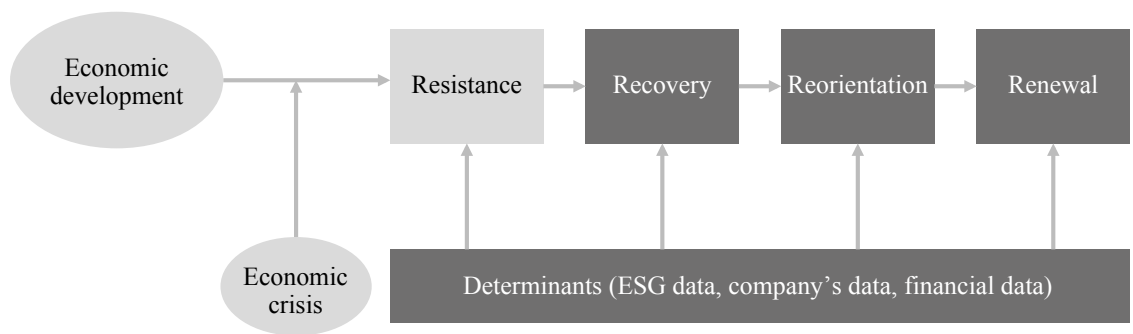

Source: compiled by authors

\section{RESEARCH DESIGN}

\subsection{Research question and hypotheses}

Based on the literature and the theoretical framework, we examine the following question and hypotheses.

Question:

- RQ: Do ESG metrics improve the measurement of crisis resilience?

Hypotheses:

- H1: ESG indicators are significant, primary variables in estimating the crisis resilience of a given firm.

- $\mathrm{H}_{2}$ : Better ESG performance can improve the crisis resilience of companies.

\subsection{Data}

Our research focuses on examining crisis resilience, highlighting the relative contribution of identified factors to explaining crisis resilience. For this, we performed calculations on companies included in the MSCI World index, $971 \mathrm{com}-$ panies altogether. At present, this pattern can be considered homogeneous, as the initial downturn during the crisis caused by the coronavirus took place in all capital markets in a similar way, as shown in Figure 2. The chart shows the performance of significant indices between March 2019-March 2021. Euronext 100 is a European equity index, NYSE Amex Composite, and Russel 2000 are indices from the USA, the Shenzen Component is a Chinese equity index, and IPC Mexico is a Mexican index. 


\section{Figure 2}

\section{Indices worldwide between March 2019- March 2021}

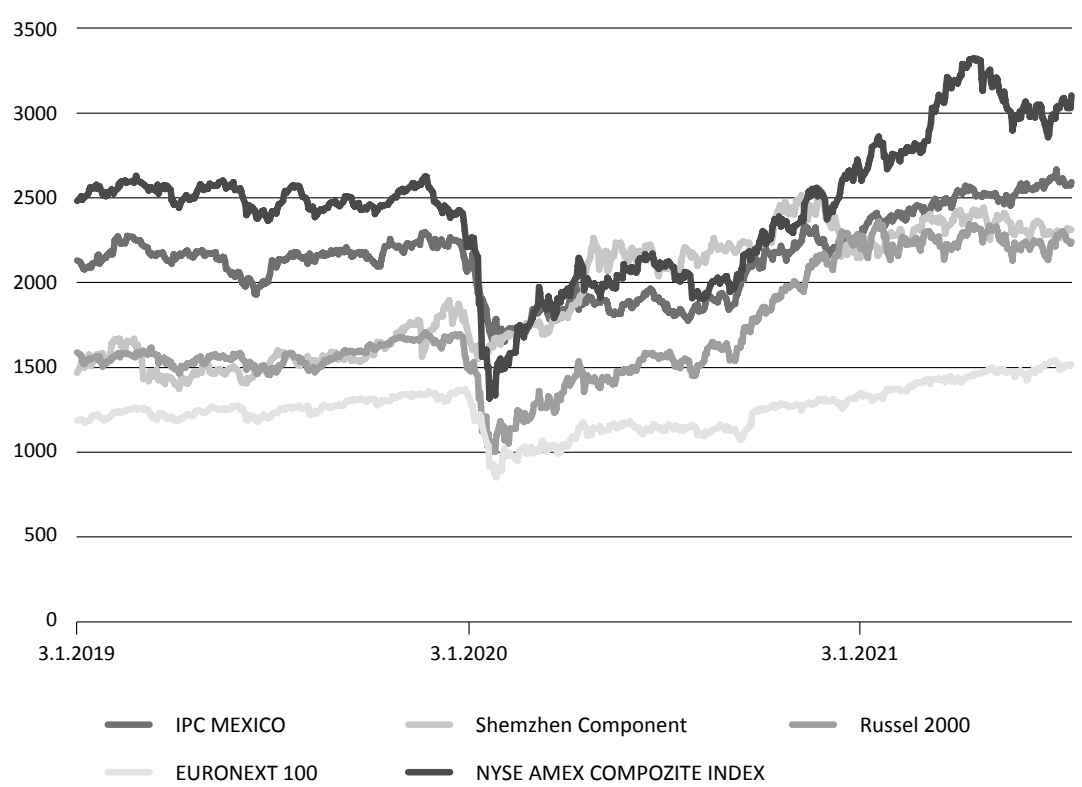

Source: Yahoo Finance, 2021

Notably, recovery from the crisis has varied across different regions and sectors depending on the recovery rate.

We used financial data from Bloomberg and ESG data from Sustainalytics. The timeframe covered the period from 1 February 2020 to 1 May 2020. We included the following explanatory variables based on the relevant literature, seen in Table 1 below.
Table 1

Variables included in the analysis

\begin{tabular}{|c|c|c|}
\hline $\begin{array}{c}\text { Type of } \\
\text { variable }\end{array}$ & $\begin{array}{l}\text { Variable } \\
\text { name }\end{array}$ & Definition \\
\hline $\begin{array}{l}\text { Resilience } \\
\text { indicator }\end{array}$ & $\begin{array}{l}\text { Maximal } \\
\text { drawdown }\end{array}$ & $\begin{array}{l}\text { The decrease from the highest point to the bottom } \\
\text { during COVID-19 (between } 20 \text { February } 2020 \text { and } \\
1 \text { May 2020). All values are negative. }\end{array}$ \\
\hline \multirow{8}{*}{$\begin{array}{l}\text { Financial } \\
\text { indicators } \\
\text { and } \\
\text { company } \\
\text { data }\end{array}$} & $\begin{array}{c}\text { Market } \\
\text { capitalization }\end{array}$ & $\begin{array}{l}\text { The company's stock market value is used to measure } \\
\text { company size (USD million) }\end{array}$ \\
\hline & Size & Natural logarithm of company's market capitalization \\
\hline & $\begin{array}{l}\mathrm{P} / \text { E ratio } \\
\text { (z score) }\end{array}$ & $\begin{array}{l}\text { The P/E ratio is the standardized monthly PE data } \\
\text { of the company's blended forward earnings } \\
\text { expectation for the past three years, considered as the } \\
\text { average, } \\
\text { and then we took the latest value from this average }\end{array}$ \\
\hline & $\begin{array}{l}\text { Financial } \\
\text { Leverage }\end{array}$ & Measures the average assets to average equity \\
\hline & Tobin Q & $\begin{array}{l}\text { The ratio of the market value of a firm } \\
\text { to the replacement cost of the firm's assets calculated } \\
\text { according to Bloomberg. }\end{array}$ \\
\hline & $\begin{array}{l}\text { Calmar } \\
\text { ratio }\end{array}$ & $\begin{array}{l}\text { A comparison of the average annual compound rate } \\
\text { of return and the maximum drawdown risk. The } \\
\text { higher the Calmar ratio, the better the performance. }\end{array}$ \\
\hline & $\begin{array}{l}\text { Implied } \\
\text { five-year } \\
\text { CDS }\end{array}$ & $\begin{array}{l}\text { Risk measure based on Bloomberg's model. The key } \\
\text { assumptions employed in the Bloomberg model } \\
\text { include ongoing as a fraction of par, piecewise } \\
\text { constant risk-neutral hazard rates, and default events } \\
\text { being statistically independent of changes in the } \\
\text { default-free yield curve. (Wen and Kinsella, 2013) }\end{array}$ \\
\hline & Volatility & $\begin{array}{c}\text { The } 360 \text {-day price volatility equals the annualized } \\
\text { standard deviation of the relative price change for the } \\
360 \text { most recent trading days' closing price. }\end{array}$ \\
\hline
\end{tabular}




\begin{tabular}{|c|c|c|}
\hline $\begin{array}{l}\text { Type of } \\
\text { variable }\end{array}$ & $\begin{array}{l}\text { Variable } \\
\text { name }\end{array}$ & Definition \\
\hline \multirow{5}{*}{ ESG data } & $\begin{array}{l}\text { ESG } \\
\text { risk score }\end{array}$ & $\begin{array}{l}\text { Overall Risk ESG score of a company based on the } \\
\text { methodology of Sustainalytics, where the lower figure } \\
\text { reflects lower risk, i.e., better ESG performance. }\end{array}$ \\
\hline & $\begin{array}{l}\text { Management } \\
\text { score }\end{array}$ & $\begin{array}{l}\text { ESG risk management performance, indicating the } \\
\text { total manageable risk exposure, how much manage- } \\
\text { ment is able to manage appropriately. }\end{array}$ \\
\hline & $\begin{array}{l}\text { Combined } \\
\text { controversies } \\
\text { score }\end{array}$ & Number of corporate ESG incidents \\
\hline & $\begin{array}{l}\text { ESG risk } \\
\text { category }\end{array}$ & $\begin{array}{l}\text { ESG Risk Ratings measure a company's exposure to } \\
\text { industry-specific material ESG risks and how well } \\
\text { a company is managing those risks. Sustainalytics } \\
\text { identifies five categories of ESG risk severity that } \\
\text { could impact a company's enterprise value: Negligible, } \\
\text { Low, Medium, High, Severe }\end{array}$ \\
\hline & $\begin{array}{l}\text { ESG Leader/ } \\
\text { Laggard }\end{array}$ & $\begin{array}{l}\text { We termed a company ESG leader if its ESG risk } \\
\text { category was Low or Negligible, and ESG laggard if } \\
\text { their category was Medium, High, or Severe. We use it } \\
\text { as a dummy variable, with the value of } 1 \text { if it is an ESG } \\
\text { leader and } 0 \text { in the case of ESG laggards. }\end{array}$ \\
\hline
\end{tabular}

Source: by the author

We selected our variables for the analysis based on the relevant literature. There are various examples of measuring crisis resilience: Cheema-Fox et al. (2020) used the difference between total corporate stock returns and total national stock returns as an explanatory variable in their work. Albuquerque et al. (2020) used three different dependent variables in their work, quarterly abnormal returns, return volatility (total and idiosyncratic volatility), and operating performance (measured by return on assets, operating profit, and asset turnover). Markman and Venzin (2014) developed their metrics for crisis resilience. To measure resilience, VOLARE (Volatility and ROE) was used, which considers volatility (a measure of risk) and long-term ROE (a measure of profitability). VOLARE motivates more objective resource allocation processes, where risky expenditures or strategies are penalized while less risky initiatives are rewarded. We applied maximal drawdown as a dependent variable, based on the definition of De Melo Mendes-Lavrado (2017) and the work of Hassan et al. (2021).

In the case of the independent variables, we chose company financial data and ESG data. The selected company financial data is based on the work of Albuquer- que et al. (2020). For ESG, based on the work of Demers et al. (2021), who used MSCI and EIKON refinitiv complex ESG measurements, we decided on the complex measurements of the Sustainalytics database.

\subsection{Methodology}

In this research, we applied a linear regression model to uncover the predictive power of ESG indicators for crisis resilience. We handled the nonlinearity in our model with algebraic linearization, which means that we took the logarithm of the variables if the variables had a positive value (Ferenczi, 2008).

We performed linear regressions in IBM SPSS statistics and Gretl 2021d. Then, we used Owen-Shapley decomposition to determine the exact contributions of the explanatory variables to the R-square of a linear regression. (Israeli, 2007) We performed the Owen-Shapley decomposition in the KNIME workspace, and we used Python language.

\section{RESULTS}

To uncover the determinants of crisis resilience, we performed a linear regression, where the dependent variable was the maximal drawdown. Firstly, we excluded the ESG variables and then we included them in our regression. We applied the forward method in all cases because this approach includes the significant variables only in the regression model. A forward algorithm is a stable approach; in each case, it can significantly increase the model's explanatory power, while it is as accurate as the other algorithms ((Bendel-Afifi, 1977).

The results of the first regression, when only financial variables were in the equation, are shown in Table 2.

Table 2

Variables in the equation - without ESG indicators (Model 1)

\begin{tabular}{cccccc}
\hline & \multicolumn{2}{c}{ Standardized Coefficients } & \multicolumn{2}{c}{$\begin{array}{c}\text { Collinearity } \\
\text { Statistics }\end{array}$} \\
& Beta & $\mathbf{t}$ & Sig. & Tolerance & VIF \\
\hline (Constant) & & 13.58801 & $9.14 \mathrm{E}-39$ & & \\
Volatility & -0.686702532 & -29.3987 & $5.4 \mathrm{E}-138$ & 0.725527 & 1.378309 \\
Calmar ratio & 0.265366844 & 11.56833 & $3.64 \mathrm{E}-29$ & 0.752285 & 1.329284 \\
P/E ratio (z score) & -0.201663635 & -9.72371 & $1.98 \mathrm{E}-21$ & 0.920328 & 1.086569
\end{tabular}




\begin{tabular}{cccccc}
\hline & \multicolumn{3}{c}{ Standardized Coefficients } & \multicolumn{3}{c}{$\begin{array}{c}\text { Collinearity } \\
\text { Statistics }\end{array}$} \\
Tobin Q & 0.140790409 & 5.944431 & $3.81 \mathrm{E}-09$ & 0.705681 & 1.417071 \\
Size & 0.091029833 & 4.125559 & $4 \mathrm{E}-05$ & 0.813078 & 1.229895 \\
Financial Leverage & -0.09867204 & -4.30405 & $1.84 \mathrm{E}-05$ & 0.753184 & 1.327698 \\
Implied 5-year CDS & -0.02 & -0.81491 & 0.415314 & 0.786417 & 1.27159 \\
\hline
\end{tabular}

Source: by the author

The R square was $59.7 \%$ in this regression. The implied CDS was not significant however, all other variables were included in the equation. The VIF values were all under 10; it can be interpreted that there is no multicollinearity in this model. In case we added the ESG indicators, we arrived at the following results.

Table 3

Variables in the equation- ESG indicators included (Model 2)

\begin{tabular}{cccccc}
\hline & \multicolumn{2}{c}{ Standardized Coefficients } & \multicolumn{2}{c}{ Collinearity Statistics } \\
& Beta & $\mathbf{t}$ & Sig. & Tolerance & VIF \\
\hline (Constant) & & 16.44379 & $4.79 \mathrm{E}-54$ & & \\
Volatility & -0.664368383 & -30.2636 & $6.6 \mathrm{E}-144$ & 0.711609 & 1.405267 \\
Calmar ratio & 0.238995588 & 11.06528 & $5.98 \mathrm{E}-27$ & 0.73513 & 1.360303 \\
$\begin{array}{c}\text { Overall management } \\
\text { score }\end{array}$ & -0.22030962 & -11.6094 & $2.4 \mathrm{E}-29$ & 0.952296 & 1.050094 \\
$\begin{array}{c}\text { P/E ratio (z score) } \\
\quad-0.18222887\end{array}$ & -9.39122 & $3.78 \mathrm{E}-20$ & 0.910812 & 1.097921 \\
$\quad \begin{array}{c}\text { Tobin Q } \\
\text { Size }\end{array}$ & 0.114121337 & 5.057807 & $5.03 \mathrm{E}-07$ & 0.673612 & 1.484534 \\
Financial Leverage & -0.132921063 & 5.942611 & $3.85 \mathrm{E}-09$ & 0.685466 & 1.458862 \\
$\quad \begin{array}{c}\text { Combined } \\
\text { controversy score }\end{array}$ & -0.065715838 & -3.15881 & 0.001631 & 0.792366 & 1.262044 \\
$\begin{array}{c}\text { Implied 5-year CDS } \\
\text { ESG leader/laggard }\end{array}$ & 0.061521789 & 2.716841 & 0.006703 & 0.66879 & 1.495239 \\
$\quad$ (dummy) & 0.003 & 0.1527 & 0.87866 & 1.51979 & 0.6476 \\
ESG Risk score & 0.009 & 0.43369 & 0.6646 & 1.1613 & 0.65805 \\
\hline
\end{tabular}

Source: by the author

We had most of the significant variables from the last regression, plus the Implied CDS, overall management, and combined controversies. The ESG Leader/ Laggard dummy variable and the ESG Risk scores were not significant. The VIF values were all under 10, and it can be interpreted that there is no multicollinearity in this model.

The R square was $65.2 \%$, which means the ESG aspect may give a plus explanatory power to our model. The results suggest that a company is less resilient if its stock is volatile, and its financial leverage is high. The higher $\mathrm{P} / \mathrm{E}$ ratio also results in worse outcomes in resilience and the beta of overall management score indicates that if a company management's ability to manage risk exposure properly is better, a company will have a larger maximal drawdown, therefore it will be less resilient. The coefficient of the combined controversy score shows us that if the number of controversies increases, companies will be less resilient. On the other hand, the Tobin Q and Calmar ratio betas suggest that overvalued stocks can be more resilient. The exclusion of the dummy variable indicates no significant difference between ESG leaders and laggards regarding crisis resilience.

To better understand the relative importance of the significant variables in explaining crisis resilience, we applied an Owen-Shapley decomposition as illustrated by Israeli (2007). Using this approach, we estimated the proportion of the explanatory power for returns that each set of variables contributes. Table 4 presents the ratio of $59.7 \%$ that is explained by each variable. As shown, volatility contributes the most to the overall $\mathrm{R}$ square, as $71.6 \%$ of the explained variation is due to this variable. $\mathrm{P} / \mathrm{E}$ ratio is second at $8.88 \%$ of the explained variation. Then come the Calmar ratio at $8.78 \%$, then the other variables, Size at $4.87 \%$, Tobin Q at $4.52 \%$, and Financial Leverage at $1.34 \%$.

In the case of Model 2, when we integrated the ESG variables, we got the following results, presented in Table 5. The total R square was $65.2 \%$ which was explained as the follows: volatility contributes the most to the overall $\mathrm{R}$ square in that case too, as $56.28 \%$ of the explained variation is due to this variable. Overall Management Score was the second at $9.93 \%$ of the explained variation. Then P/E ratio and the Implied CDS had both around $7.49 \%$ and $7.09 \%$, then the other variables, Calmar ratio at $6.39 \%$, Size at $6.38 \%$, Tobin Q ratio at $3.32 \%$, Combined controversy score at $2.19 \%$, and Financial leverage at $0.94 \%$.

To sum up the ESG variable, the Overall management score is second in importance, contributing 9.93\% of the total $65.2 \%$ explained variation in returns during the first quarter of the COVID crisis. The Combined controversy score contributed at $2.19 \%$ of the total explained variation.

Taken together, our results from these regression analyses and the Owen-Shapley decomposition suggest that company, financial, and ESG variables are all important in explaining crisis resilience during COVID Crisis. 
Table 4

Relative contribution of identified factors

to explaining crisis resilience in case of Model 1

\begin{tabular}{cc}
\hline Variable & $\begin{array}{c}\text { The relative contribution } \\
\text { of identified factors }\end{array}$ \\
\hline Volatility & $71.60 \%$ \\
P/E ratio (z score) & $8.88 \%$ \\
Calmar ratio & $8.78 \%$ \\
Size & $4.87 \%$ \\
Tobin Q ratio & $4.52 \%$ \\
Financial leverage & $1.34 \%$ \\
\hline
\end{tabular}

Source: by the author

\section{Table 5}

\section{Relative contribution of identified factors}

to explaining crisis resilience in case of Model 2

\begin{tabular}{cc}
\hline Variable & $\begin{array}{c}\text { The relative contribution } \\
\text { of identified factors }\end{array}$ \\
\hline Volatility & $56.28 \%$ \\
Overall Management Score & $9.93 \%$ \\
PE ratio (z score) & $7.49 \%$ \\
Implied CDS & $7.09 \%$ \\
Calmar ratio & $6.39 \%$ \\
Size & $6.38 \%$ \\
Tobin Q ratio & $3.32 \%$ \\
Combined controversies score & $2.19 \%$ \\
Financial leverage & $0.94 \%$ \\
\hline
\end{tabular}

Source: by the author

Overall, the combined results from our linear regression and Owen-Shapley decomposition analyses present a comprehensive picture of ESG variables: these factors can be a potential resilience factor during the covid crisis because ESG indicators could provide a plus explanatory power for crisis resilience models. However, the findings suggest that the association between ESG performance and stock performance is not clear. We have failed to find evidence of a significant difference between ESG leaders and ESG laggards regarding crisis resilience. On the other hand, the regression model results suggest that ESG performance can both improve and worsen a company's crisis resilience.

Based on these results, we did not reject the H1 hypothesis that ESG indicators were significant and primary variables in estimating the crisis resilience of a given firm. On the other hand, we rejected the $\mathrm{H}_{2}$ hypothesis, i.e., that better ESG performance can improve the crisis resilience of companies.

\section{SUMMARY}

We examined the role of ESG indicators in explaining the crisis resilience of companies during the COVID-19 crisis. The outbreak of the pandemic in February 2020 acted as a significant external shock to global stock markets. Our findings show that ESG metrics, particularly the overall management score, and the combined controversy score, can be good predictors of company-level crisis resilience. However, our other results suggest that better ESG performance cannot fully improve the crisis resilience of companies.

Our results align with the literature: Ferriani and Natoli (2020) highlighted in their study that the investors took ESG risk significantly into account during the COVID-19 crisis. They also found that E, S, and G factors have not been valued the same, as a particular preference is shown for funds with low governance and environmental risks. Finally, Diaz et al. (2021) showed that ESG is indispensable to understand the factors of investment decisions during uncertain times. The role of ESG metrics in improving crisis resilience is still unclear; further empirical tests are needed to evaluate this question. Demers et al. (2021) and Liang-Renneboog (2020) also highlighted the mixed view of ESG performance on corporate performance in their work.

Our results highlight the importance of sustainability considerations for explaining crisis resilience. Implications of this research support the shift from shareholder to stakeholder capitalism as reflected by global equity market performance during this pandemic, which acted as an external shock. This shift is also visible in the risk management of investments, as more empirical evidence highlights the importance of sustainability-related risk management. The importance of sustainability aspects in finance and investments is increasing, according to Schoenmaker-Schramade (2019). Dijk (2020) provides a reasonable basis for this, which is yet to be further developed in practice. 


\section{REFERENCES}

AlbuQuerque, R. - Koskinen, Y. - YANG, S. - Zhang, C. (2020): Resiliency of environmental and social stocks: An analysis of the exogenous COVID-19 market crash. The Review of Corporate Finance Studies, 9(3), 593-621. https://doi.org/10.1093/rcfs/cfaao11.

Alessi, L. - Benczur, P. - Campolongo, F. - Cariboni, J. - Manca, A. R. - Menyhert, B. - PaGANO, A. (2020): The resilience of EU member states to the financial and economic crisis. Social Indicators Research, 148(2), 569-598. https://doi.org/10.1007/s11205-019-02200-1.

Armeanu, D. Ş. - Vintilă, G. - Gherghina, Ş. C. - Petrache, D. C. (2017): Approaches on correlation between board of directors and risk management in resilient economies. Sustainability 9(2), 173. https://doi.org/10.339o/su9020173.

BENDEL, R. B. - Afifi, A. A. (1977) Comparison of stopping rules in forward "stepwise" regression. Journal of the American Statistical Association, 72(357), 46-53. https://doi.org/10.1080/01621459 .1977 .10479905 .

BerLinger, E. - Keresztúri, J. L. - TAMÁSNÉ VőNeki, Zs. (2018) A cross-country analysis of operational risk: The effect of the freedom of press. In PRMIA Hungary Chapter Annual Conference, 8

Bloomberg (2021): Global Indices. Available at: Bloomberg Terminal. Accessed: 20 July 2021.

Broadstock, D. C. - Chan, K. - Cheng, L. T. - Wang, X. (2021): The role of ESG performance during times of financial crisis: Evidence from COVID-19 in China. Finance Research Letters 38 101716. https://doi.org/10.1016/j.frl.2020.101716

Bouslah, K. - Kryzanowski, L. - Bouchra, M. Z. (2018): Social performance and firm risk: Impact of the financial crisis. Journal of Business Ethics, 149, 643-669. https://research-repository.st-andrews.ac.uk/bitstream/handle/10023/8244/Bouslah_JBE2016_SocialPerformance cc.pdf?sequence $=1$ \&isAllowed $=y$.

CASTro, M. P. - Zermeño, M. G. G. (2020): Being an entrepreneur post- COVID-19-resilience in times of crisis: a systematic literature review. Journal of Entrepreneurship in Emerging Economies, https://doi.org/10.1108/jeee-07-2020-0246.

Cheema-Fox, A. - LaPerla, B. R. - Serafeim, G..-Wang, H. S. (2020): Corporate resilience and response during COVID-19. Available at SSRN 3578167, https://doi.org/10.2139/ssrn.3578167

Demers, E. - Hendrikse, J. - Joos, P. - Lev, B. (2021): ESG did not immunize stocks during the COVID-19 crisis, but investments in intangible assets did. Journal of Business Finance \& Accounting, 48(3-4), 433-462. https://doi.org/10.1111/jbfa.12523.

Díaz, V. - Ibrushi, D. - ZhaO, J. (2021): Reconsidering systematic factors during the COVID-19 pandemic - The rising importance of ESG. Finance Research Letters, 38, 101870. https://doi. org/10.1016/j.frl.2020.101870

Ding, W. - Levine, R. - LiN, C. - XIE, W. (2021): Corporate immunity to the COVID-19 pandemic. Journal of Financial Economics, 141(2), 802-830. https://doi.org/10.1016/j.jfineco.2021.03.005.

Ding, W. - Levine, R. - LIN, C. - XIE, W. (2020): Corporate immunity to the COVID-19 pandemic (No. w27055). National Bureau of Economic Research. https://doi.org/10.3386/w27055.

European Commission (2021a): Sustainable Finance. Available at https://ec.europa.eu/info/business-economy-euro/banking-and-finance/sustainable-finance_en.

European Commission (2021b): Corporate sustainability reporting. Available at https://ec.europa eu/info/business-economy-euro/company-reporting-and-auditing/company-reporting/corporate-sustainability-reporting_en.

FerenczI, T. (2008): Nemlineáris modellek [Non-linear models] (online). Available at http://www. medstat.hu (downloaded at 20.10.2021).
Ferriani, F. - Natoli, F. (2020): ESG risks in times of COVID-19. Applied Economics Letters, 1-5. https://doi.org/10.1080/13504851.2020.1830932

Godfrey, P. C. - Merrill, C. B. - Hansen, J. M. (2009): The relationship between corporate social responsibility and shareholder value: An empirical test of the risk management hypothesis. Strategic Management Journal, 30, 425-445. https://onlinelibrary.wiley.com/doi/pdfdirect/10.1002/ smj.750.

GÜNTHER, T. - GLEISSNER, W. - WALKSHÄUSL, C. (2020): What happened to financially sustainable firms in the Corona crisis?. In Sustainability Management Forum/Nachhaltigkeits Management Forum, 28(3), 83-9o. Heidelberg-Berlin: Springer. https://doi.org/10.1007/so0550-020-00503-3.

Hassan, M. K. - ChowdhurY, M. I. H. - Balli, F.,-Hasan, R. (2021): A note on COVID-19 instigated maximum drawdown in Islamic markets versus conventional counterparts. Finance Research Letters, 102426. https://doi.org/10.1016/j.frl.2021.102426.

IsRAELI, O. (2007): A Shapley-based decomposition of the R-square of a linear regression. The Journal of Economic Inequality, 5(2), 199-212. https://doi.org/10.1007/s10888-006-9036-6.

Liang, H. - Renneboog, L. (2020): Corporate social responsibility and sustainable finance: A review of the literature. European Corporate Governance Institute - Finance Working Paper, 701. https://doi.org/10.2139/ssrn.3698631.

Lys, T. - NAUGhTON, J. P. - WANG, C. (2015): Signaling through corporate accountability reporting. Journal of Accounting and Economics, 60, 56-72. https://www.sciencedirect.com/science/article/ pii/So16541011500o191.

Markman, G. M. - Venzin, M. (2014): Resilience: Lessons from banks that have braved the economic crisis - And from those that have not. International Business Review, 23(6), 1096-1107. https://doi.org/10.1016/j.ibusrev.2014.06.013.

MARTIN, R. (2012): Regional economic resilience, hysteresis and recessionary shocks. Journal of economic geography, 12(1), 1-32. https://doi.org/10.1093/jeg/lbro19.

De Melo Mendes, B. V. - Lavrado, R. C. (2017) Implementing and testing the Maximum Drawdown at Risk. Finance Research Letters, 22, 95-100. https://doi.org/10.1016/j.frl.2017.06.001.

MSCI (2016), MSCI ESG Government Ratings. Available at https://www.msci.com/documents/10199/ eog2c439-34e1-4055-8491-86fb0799c38f.

NAfFA, H. - FAIN, M. (2020): Performance measurement of ESG-themed megatrend investments in global equity markets using pure factor portfolios methodology. PLoS ONE, 15(12), 1-34. https:// doi.org/10.1371/journal.pone.0244225.

NÉмETh-DURкó, E. (2020): Environment and finance: Impact of financial development on carbon emissions. Rconomy and Finance, 7(4), 425-440. https//bankszovetseg hu/Public/gep/2020/4 $440 \% 20$ Nemeth\%20E\%20Eng.pdf.

Oprea, F. - Onofrei, M. - Lupu, D. - Vintila, G. - Paraschiv, G. (2020): The determinants of economic resilience. The case of Eastern European regions. Sustainability, 12(10), 4228. https:// doi.org/10.3390/su12104228.

Primecz, H. - Havran, D. - Lakatos, Z. (2019). How Does Female Presence on the Management and Supervisory Boards Impact the Performance in CEE? Academy of Management Annual Meeting Proceedings, 2019(1), 1-1. https://doi.org/10.5465/ambpp.2019.10602abstract.

Sabatino, M. (2016): Economic crisis and resilience: Resilient capacity and competitiveness of the enterprises. Journal of Business Research, 69(5), 1924-1927. https://doi.org/10.1016/j.jbusres.2015.10.081.

SChoenmaker, D. - Schramade, W. (2019) Investing for long-term value creation. Journal of Sustainable Finance and Investment, 9(4), 356-377. https://doi.org/10.1080/20430795.2019.1625012.

Sовока, A. - Bristow, G. - Naim, M. - Purvis, L. (2020): Measuring regional business resilience. Regional Studies, 54(6), 838-850. https://doi.org/10.1080/00343404.2019.1652893. 
TAMÁsné VőNEKI, Zs. - LAmANDA, G. (2020). Content analysis of bank disclosures related to esg risks. A snapshot of the disclosure practices of large domestic banks. Economy and Finance, 7(4), 412-424. https://bankszovetseg.hu/Public/gep/2020/412-424\%20Tamasne\%2oVZS\%2oEng.pdf.

VAN Dijк, M. A. (2020): Assessing climate risk for investment portfolios. Available at https://www. netspar.nl/assets/uploads/Session-2c_Van-Dijk.pdf.

Wen, Y. - Kinsella, J. (2013): Credit Default Swap-Pricing Theory, Real Data Analysis and Classroom Application Using Bloomberg Terminal. New York, https:/data.bloomberglp.com/bat/ sites/3/2016/10/WhitePaper_Wen.pdf.

Yahoo Finance (2021) World Indices [online]. Available at https://finance.yahoo.com/world-indices?. tsrc=fin-srch (downloaded: 20.10.2021). 